\title{
Houttuynia cordata Thunb extract induces apoptosis through mitochondrial-dependent pathway in HT-29 human colon adenocarcinoma cells
}

\author{
YIH-JING TANG ${ }^{1,2}$, JAI-SING YANG ${ }^{3,4}$, CHIN-FEN LIN ${ }^{5}$, WOEI-CHERNG SHYU ${ }^{6}$, \\ MINORU TSUZUKI ${ }^{7,4}, \mathrm{CHI}-\mathrm{CHENG} \mathrm{LU}^{8}$, YUH-FUNG CHEN ${ }^{9,4,10}$ and KUANG-CHI LAI ${ }^{11,4,10}$ \\ ${ }^{1}$ Department of Family Medicine, Taichung Veterans General Hospital; ${ }^{2}$ School of Medicine, \\ Chung-Shan Medical University; ${ }^{3}$ Department of Pharmacology; ${ }^{4}$ Tsuzuhi Institute for Traditional Medicine; \\ ${ }^{5}$ Department of Biochemistry; ${ }^{6}$ Graduate Institute of Immunology, China Medical University, Taichung, Taiwan, R.O.C.; \\ ${ }^{7}$ Nihon Pharmaceutical University, Ina, Saitama, Japan; ${ }^{8}$ Department of Life Sciences, National Chung Hsing University, \\ Taichung 402; ${ }^{9}$ Graduate Institute of Chinese Pharmaceutical Sciences; ${ }^{10}$ School of Medicine, China Medical University, \\ Taichung; ${ }^{11}$ Department of Surgery, China Medical University Beigang Hospital, Beigang, Yunlin, Taiwan, R.O.C.
}

Received June 29, 2009; Accepted August 10, 2009

DOI: $10.3892 /$ or_00000535

\begin{abstract}
The Houttuynia cordata Thunb (HCT) extract has been used as a traditional Chinese herb medicine and as well as an effective drug for treating allergic inflammation for thousands of years. In this study, we investigated the anticancer activity of HCT and its molecular mechanisms in the human colon adenocarcinoma cell line HT-29. HCT inhibited HT-29 cell viability in a dose- and time-dependent manner by MTT assay. Treatment with $450 \mu \mathrm{g} / \mathrm{ml}$ of HCT for 48 and $72 \mathrm{~h}$ led to DNA damage and apoptosis by DAPI staining and comet assay. HCT increased reactive oxygen species production and decreased the levels of mitochondria membrane potential (MMP) in HT-29 cells by flow cytometry analysis. HCT caused the release of cytochrome c, Apaf-1, pro-caspase-9 and AIF from mitochondria via a decrease of the MMP. The decrease of MMP was then associated with a decrease in the ratio of Bax/Bcl-2 and activation of caspase- 9 and -3 by Western blotting and caspase activity assay. Caspase- 9 and -3 inhibitors almost
\end{abstract}

Correspondence to: Dr Kuang-Chi Lai, Department of Surgery, China Medical University Beigang Hospital, Beigang Township, Yunlin 651, Taiwan, R.O.C.

E-mail: kuangchi_lai@hotmail.com

Dr Yuh-Fung Chen, Graduate Institute of Chinese Pharmaceutical Sciences, China Medical University, No 91, Hsueh-Shih Road, Taichung 404, Taiwan, R.O.C.

E-mail: yfchen@mail.cmu.edu.tw

Key words: Houttuynia cordata Thunb, human colon adenocarcinoma cell line HT-29, apoptosis, mitochondrial-dependent pathway completely suppressed HCT-induced caspase- 9 and -3 activities. Our results demonstrated that the HCT-induced apoptosis in human colon adeno-carcinoma cell line HT-29 might be related to a mitochondrial- dependent pathway.

\section{Introduction}

In Taiwan, $\sim 15.03$ persons per 100,000 people died per year from colon cancer, according to the reports of the 'People Health Bureau of Taiwan' (1). In clinical practice, surgery, radiotherapy and chemotherapy are used for treating colon cancer patients (2). However, the current strategies for treatment of human colon cancer are limited and the results are not yet satisfactory. Induction of apoptosis in cancer cells has been considered as an important strategy in cancer treatment (3). Many anti-cancer drugs can inhibit tumor cell growth by apoptosis induction $(4,5)$.

Apoptosis is a normal component of the development and physical condition of cellular organisms. Many studies have focused on selectively killing cancer cells through the induction of apoptosis $(6,7)$. Apoptosis is a kind of cell death that causes specific morphological modification such as cell membrane blebbing, chromatin condensation, caspases activation and DNA fragmentation that are considered landmarks of the apoptotic process (8-10). Present studies demonstrated that mitochondria are important in regulation of apoptosis $(11,12)$. Mitochondrial changes include decrease of mitochondrial membrane potential (MMP), increase of reactive oxygen species (ROS) production, release of cytochrome c, Apaf-1 and pro-caspase-9 proteins from mitochondria to cytosol and then activation of caspases $(11,13,14)$. The activation of effector caspases (caspase-3, -6 and -7) by initiator caspases (caspase-2, -8, -9 and -10) are responsible for the cleavage of cellular substrates including lamin and poly (ADP-ribose) polymerase (PARP) $(15,16)$. Cleavage of those substrates degrades the chromosomes into nucleosomal fragments during apoptosis (17). 
Hottuynia cordata Thunb is a perennial herb that is native to Southeast Asia (18) and it has a thin stalk and heart-like leaf. It is called E-Sung-Cho in China and it is known to be an effective drug for treating allergic inflammation (19). Previous studies concluded that the HCT is effective for treating anaphylaxis, cancer and viral infection (20-22). Recently, many studies also demonstrated anti-leukemic activity (21), anticancer activity (23) and anti-oxidant action (24) of Hottuynia cordata Thunb extract (HCT). However, the molecular mechanism underlying apoptosis induction by HCT in colon cancer cells are not well understood. In the present study, we investigated the anti-cancer molecular mechanism of HCT in the human colon adenocarcinoma cell line HT-29.

\section{Materials and methods}

Preparation of HCT. Hottuynia cordata Thunb 50\% ethanol extracts of PR (yield: $6.73 \%$ of dry wt.) were obtained by $48 \mathrm{~h}$ maceration at room temperature. The ethanol extract was filtered through a $0.45-\mu \mathrm{m}$ filter (Osmonics, Minnetonka, MN, USA), lyophilized and kept at $4^{\circ} \mathrm{C}$. The dried extract was resolublized in PBS before use.

Chemicals and reagents. 3-(4,5-dimethylthiazol-2-yl)-2,5diphenyltetrazolium bromide (MTT), propidium iodide (PI); DAPI; low-melting agarose (Sigma, St. Louis, MO); RPMI-1640, fetal bovine serum (FBS), trypsin-EDTA and penicillin/streptomycin (Gibco BRL). Proteinase K was purchased from Roche Diagnostics $(\mathrm{GmbH}$, Mannheim, Germany). The Bio-100TM DNA Ladder marker was obtained from PROtech Technology Enterprise Co. (Taipei, Taiwan). All other chemicals used were of analytical grade.

Cell culture. Human colon adenocarcinoma cell line HT-29 was obtained from the American Type Culture Collection. Cells were maintained in RPMI-1640 containing 100 ml/l FBS with $100,000 \mathrm{U} / 1$ penicillin and $100 \mathrm{mg} / \mathrm{l}$ streptomycin (24).

MTT assay. HT-29 cells were plated onto 96-well plates and exposure to HCT as detailed in respective experiments for 24 and $48 \mathrm{~h}$. MTT was added to each well then incubated for an additional $4 \mathrm{~h}$ in dark at $37^{\circ} \mathrm{C}$. The medium was then aspirated from the wells and the blue formazan product was dissolved in $100 \mu \mathrm{l}$ of DMSO. The plates were analyzed at O.D. $570 \mathrm{~nm}$ using a spectrophotometric plate reader (Bio-Rad, Tokyo, Japan). Each data point was replicated in triplicate. Percentage of cell viability was calculated as (O.D. of drugtreated sample/O.D. of non-treated sample) x100\% (24).

DAPI staining. After HCT treatment, cells were fixed in $4 \%$ paraformaldehyde for $30 \mathrm{~min}$ and incubated with $1 \mu \mathrm{g} / \mathrm{ml}$ of DAPI staining solution for $30 \mathrm{~min}$ in the dark. The apoptotic cells were observed through fluorescence microscopy (Zeiss, Oberköchen, Germany) (25).

Comet assay. Each slide of 10,000 cells were mixed with $150 \mu 10.75 \%$ low-melting agarose (Sigma type VII, USA) held at $37^{\circ} \mathrm{C}$. The agarose was spread into single layers on ordinary, clear-glass slides that had been pre-treated with a small amount of agarose and air-dried. After solidifying on a

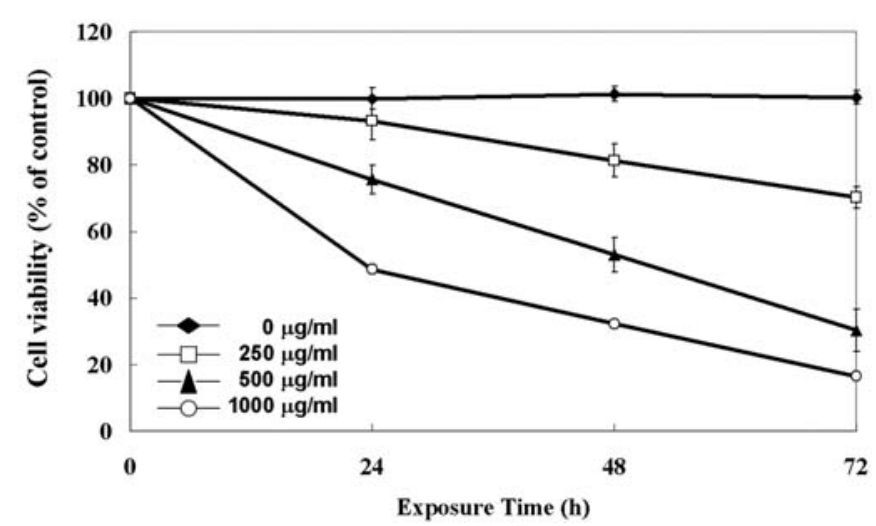

Figure 1. Effects of HCT on cell viability of human colon adenocarcinoma cell line HT-29. Cells were treated with various concentrations of HCT for 24,48 and $72 \mathrm{~h}$ by MTT assay. Results are presented as mean \pm SD. The experiments were done in triplicate.

chilled plate, the slides were transferred to the same lysis buffer and held at room temperature for $4 \mathrm{~h}$, when appropriate in the presence of DAPI as above (26).

ROS production assay. ROS was measured after staining with DCFH-DA dye in HT-29 cells. Cells were collected and washed with PBS. One ml of PBS containing $20 \mu \mathrm{M}$ DCFHDA was added and the cells were incubated for $30 \mathrm{~min}$ at $37^{\circ} \mathrm{C}$. The fluorescence emission from DCF was analyzed by flow cytometry (Becton-Dickinson, San Jose, CA) (27).

MMP assay. Changes of MMP were monitored after staining with $\mathrm{DiOC}_{6}$. HT-29 cells were collected, trypsinized and washed in PBS, then they were stained with $\mathrm{DiOC}_{6}(5 \mu \mathrm{g} / \mathrm{ml})$ for $30 \mathrm{~min}$ at $37^{\circ} \mathrm{C}$. The percentage of green fluorescence was estimated by flow cytometry (28).

Western blotting. Total cell lysates were prepared, as described previously $(29,30)$. Assay kits for cytosolic proteins (Calbiochem, Germany) were used to assess the release of cytochrome c, Apaf-1, AIF and pro-caspase-9 from mitochondria to cytosol and the purity of the fractions estimated (31). The $30 \mu \mathrm{g}$ proteins were resolved on SDS-PAGE and transferred onto a polyvinylidene fluoride membrane (PVDF; Millipore). After blocking, the blots were incubated with an appropriate dilution of specific monoclonal antibodies for cytochrome c, Apaf-1, pro-caspase-9, AIF, Bax, Bcl-2, and xIAP (Santa Cruz Biotechnology, USA) for $12 \mathrm{~h}$. Blots were washed three times and then incubated with horseradish peroxidase-conjugated secondary antibody (Santa Cruz Biotechnology). The specific protein was detected by using enhanced chemiluminescence kits (Amersham, ECL kits) (30).

Caspase activity assay. HT-29 cells were collected in lysis buffer (50 mM Tris-HCl, 1 mM EDTA, 10 mM EGTA, 10 mM digitonin and $2 \mathrm{mM}$ DTT) on ice for $10 \mathrm{~min}$. The lysates were centrifuged at $15,000 \mathrm{xg}$ at $4^{\circ} \mathrm{C}$ for $10 \mathrm{~min}$. Cell lysates $(50 \mu \mathrm{g}$ protein) were incubated with caspase-3, -9 and -8-specific substrates (Ac-DEVD-pNA, Ac-LEHD-pNA and Ac-IETDpNA) with reaction buffer in a 96-well plate at $37^{\circ} \mathrm{C}$ for $1 \mathrm{~h}$. 
A

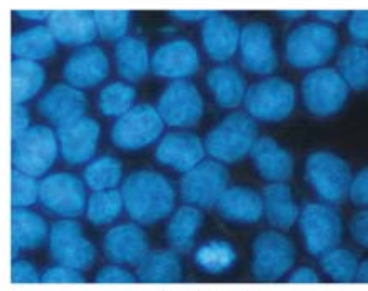

Control

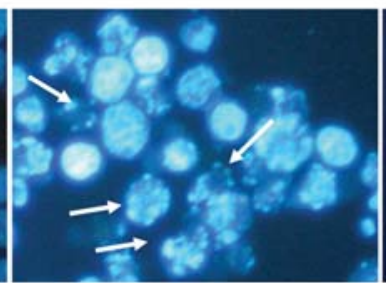

$48 \mathrm{~h}$

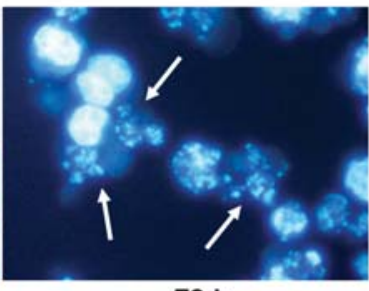

$72 \mathrm{~h}$

Exposure Time on $450 \mu \mathrm{g} / \mathrm{ml}$ of HCT

B

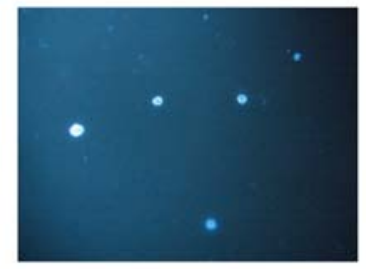

Control

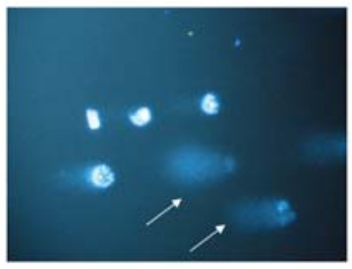

$225 \mu \mathrm{g} / \mathrm{ml}$

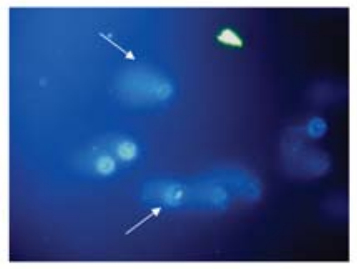

$450 \mu \mathrm{g} / \mathrm{ml}$

Exposure Time (72 h)

Figure 2. Effects of HCT on DNA damage and apoptosis of human colon adenocarcinoma cell line HT-29. (A) Nuclear morphology of HT-29 cells stained with DAPI after 48 and $72 \mathrm{~h}$ of treatment with $450 \mu \mathrm{g} / \mathrm{ml}$ of HCT. (B) DNA breaks by Comet assay (single cell gel electrophoresis) of HT-29 cells after $72 \mathrm{~h}$ of treatment with 225 and $450 \mu \mathrm{g} / \mathrm{ml}$ of HCT. Cells were examined and photographed under fluoresce microscopy (x200) as described in Materials and methods.

A
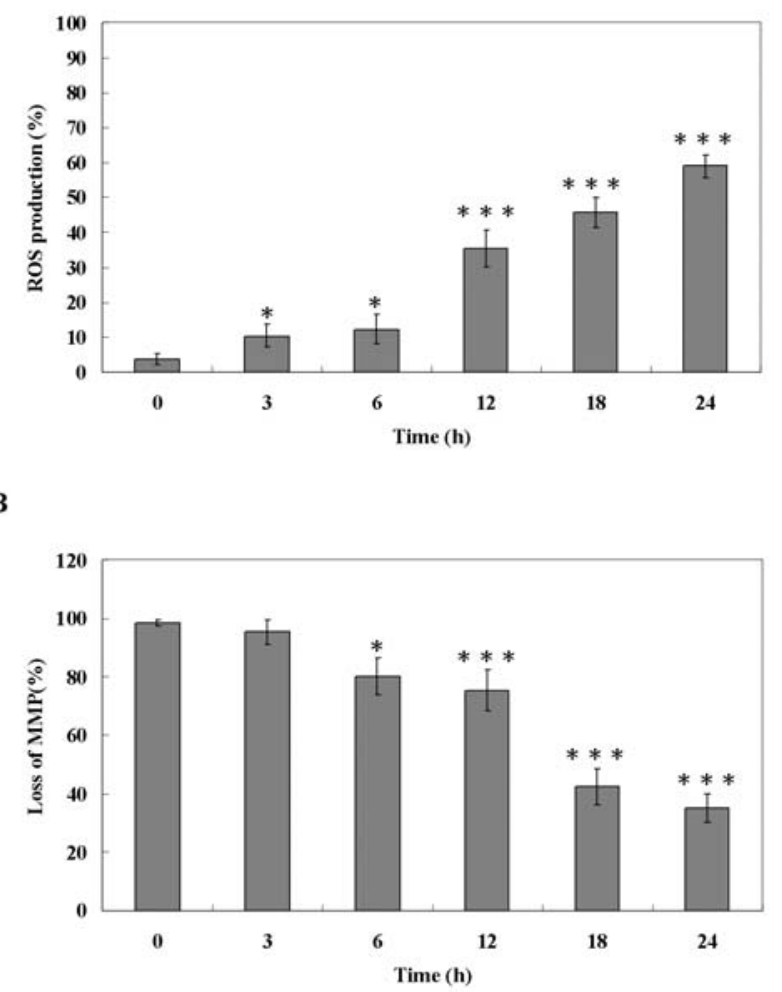

Figure 3. Flow cytometric analysis of ROS production (A) and loss of mitochondrial membrane potential (B). HT-29 cells were treated with $450 \mu \mathrm{g} / \mathrm{ml}$ of HCT then detected for the changes of ROS production and loss of MMP. The zero concentration was defined as control. The percentage of cells that were detected for ROS and MMP by DCFH-DA, DiOC 6 dye and the stained cells were determined by flow cytometry, as described in Materials and methods. ${ }^{*} \mathrm{P}<0.05,{ }^{* *} \mathrm{P}<0.01,{ }^{* * *} \mathrm{P}<0.001$.
The caspase activity was determined by measuring OD 405 of the released pNA (31).

Statistical analysis. Student's t-test was used to analyze differences between HCT-treated and control groups. ${ }^{*} \mathrm{P}<0.05$, ${ }^{* *} \mathrm{P}<0.01,{ }^{* * *} \mathrm{P}<0.001$.

\section{Results}

HCT inhibits cell viability of HT-29 cells. Cells were treated with HCT at concentrations of $0,250,500$ and $1000 \mu \mathrm{g} / \mathrm{ml}$. Cell viability was determined by MTT assay 24, 48 and $72 \mathrm{~h}$ later. As shown in Fig. 1, HCT inhibited cell viability in HT29 cells in a dose- and time-dependent manner. The concentration required for inhibiting growth by $50 \%\left(\mathrm{IC}_{50}\right)$ for $72 \mathrm{~h}$ on HT-29 cells was $\sim 435 \mu \mathrm{g} / \mathrm{ml}$.

HCT induces morphological changes and DNA damage in HT-29 cells. To verify whether HCT could inhibit cell viability through induction of apoptosis and DNA damage in HT-29 cells, we assessed the nuclear morphological change by DAPI staining and DNA damage by Comet assay (single cell gel electrophoresis). As shown in Fig. 2A and B, after 48 and $72 \mathrm{~h}$ incubation with $450 \mu \mathrm{g} / \mathrm{ml}$ of HCT, cells exhibited nuclear shrinkage and chromatin condensation. Less than $1 \%$ of the control cells showed evidence of DNA damage in the form of the typical tail formation. Cells exposed to HCT exhibited dose-dependent increase in DNA damage by Comet assay. Our results demonstrated that the HCT could induce morphological change and DNA damage in HT-29 cells. 
A

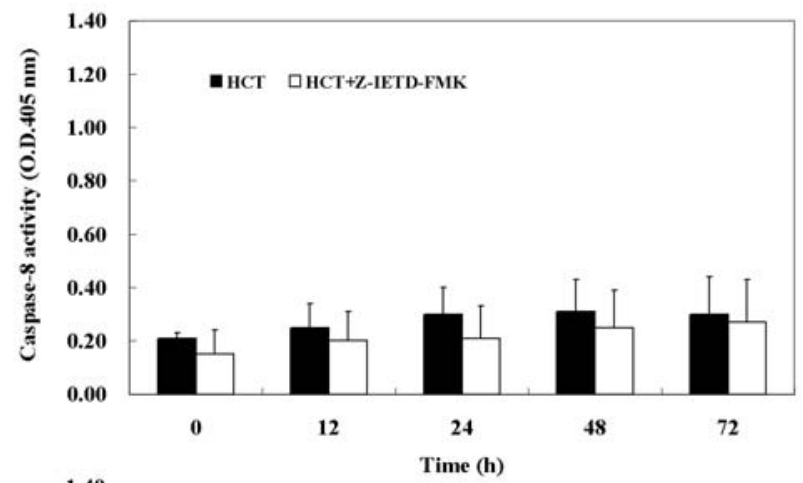

B

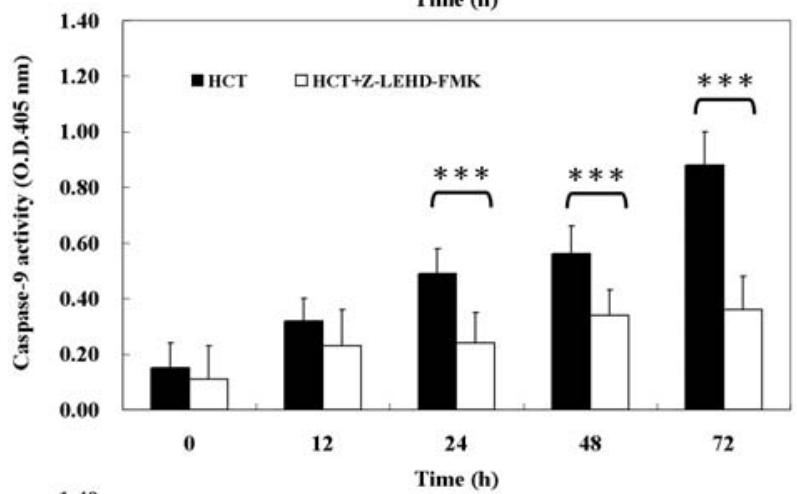

C

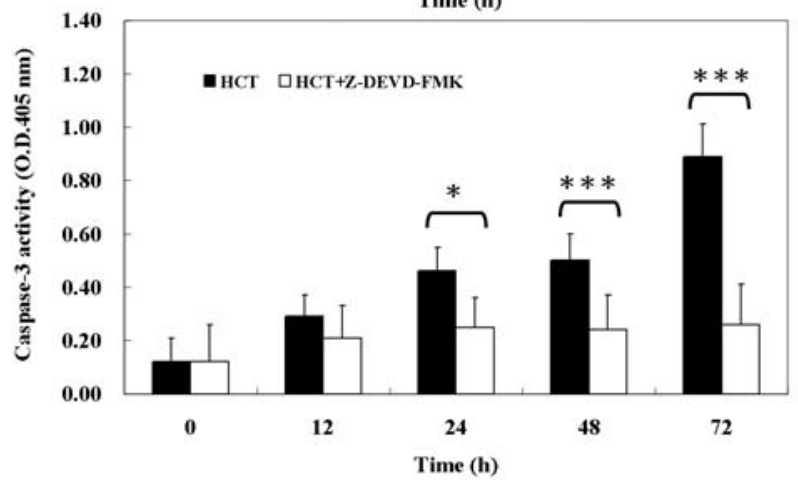

Figure 4. HCT stimulated caspases-9 and -3 activities in HT-29 cells. Cells were pretreated with the caspase- 8 inhibitor (Z-IETD-FMK), caspase- 9 inhibitor (Z-LEHD-FMK) and caspase-3 inhibitor (Z-DEVE-FMK), for $1 \mathrm{~h}$ and then treated with $450 \mu \mathrm{g} / \mathrm{ml}$ of HCT for incubated various time of periods The total cell extracts were incubated with caspases-3, -9 and -8-specific substrates, respectively (Ac-DEVD-pNA, Ac-LEHD-pNA and Ac-IETDpNA). The release of pNA was measured at $405 \mathrm{~nm}$ by a spectrophotometer. The experiments were done in triplicate. ${ }^{*} \mathrm{P}<0.05,{ }^{* *} \mathrm{P}<0.01,{ }^{* * *} \mathrm{P}<0.001$.

HCT induces ROS production and loss of MMP in HT-29 cells. To verify whether HCT could cause cell apoptosis through induction of mitochondria stress in HT-29 cells, we measured the intracellular ROS level and MMP change. As shown in Fig. 3, HT-29 cells were treated with $450 \mu \mathrm{g} / \mathrm{ml}$ of $\mathrm{HCT}$, cells showed significant decrease in MMP and increase level of ROS. Our results suggested that the mitochondria dysfunction may be involved in HCT-induced apoptosis and ROS may play a key role in this pathway.

HCT induces apoptosis by the activation of Caspase-9 and -3. We investigated the HCT-treated HT-29 cells for caspase-9, caspase- 8 and caspase- 3 activities by colorimetric enzymatic assay. As shown in Fig. 4A, B and C, both caspase-9 and -3 activities increased at $12 \mathrm{~h}$ after HCT treatment. Our results suggested that the HCT-induced apoptosis was mediated
A

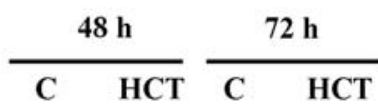

Cytochrome $c$

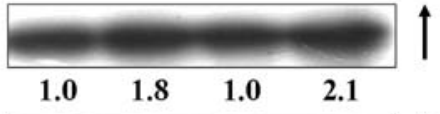

Apaf-1

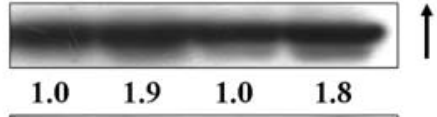

Pro-caspase-9

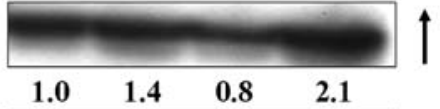

AIF

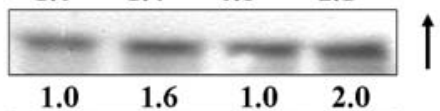

$\beta$-Actin

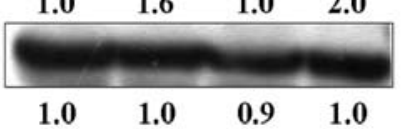

B

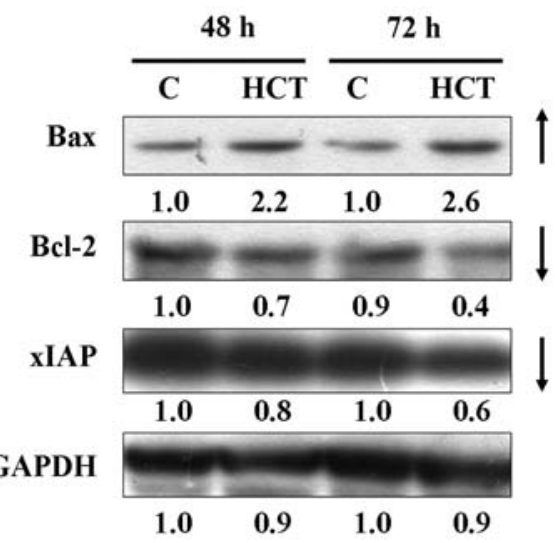

Figure 5. Effects of HCT-induced apoptotic relative protein levels on HT-29 cells. (A) Western blot analysis for cytosolic cytochrome c, Apaf-1, procaspase-9 and AIF in HCT-examined cells. (B) Western blot analysis for Bax, Bcl-2 and xIAP protein levels. For Western blot analysis, total or cytosolic protein extracts were analyzed by immunoblotting.

through the activation of caspase- 9 and -3 . To further verify the involvement of caspases- 9 and caspases-3 in HCTinduced apoptosis of HT-29 cells, caspase-9 inhibitor (ZLEHD-FMK) and caspase-3 inhibitor (Z-DEVE-FMK) were pretreated. Our results demonstrated that Caspase-9 inhibitor (Z-LEHD-FMK) and caspase-3 inhibitor (Z-DEVE-FMK) almost completely suppressed HCT-induced caspase-9 and -3 activity and they also increased the viable HT-29 cells.

Effects of HCT on levels of apoptosis-associated proteins in HT-29 cells. To study the mechanisms of HCT induced apoptosis, we investigated the protein expression of cytochrome c, Apaf-1, AIF and pro-caspase-9 in cytosolic lysates and $\mathrm{Bcl}-2$, xIAP, Bax protein expression by Western blot analysis. Fig. 5A shows the release of cytochrome c, Apaf-1, AIF and pro-caspase-9 from the mitochondria into the cytosol after treatment with HCT for $24 \mathrm{~h}$. As shown in Fig. 5B, HCT decreased the levels of Bcl-2, xIAP and increased the levels of Bax. Our results suggested that the HCT-induced apoptotic response is mediated by a mitochondrial pathway. 


\section{Discussion}

Houttuynia cordata Thunb (HCT) has been used as food and traditional Chinese herb medicine in South Asia including Taiwan for a very long time. The biologic activity of HCT includes anti-microbial, anti-viral, immuno-regulatory, diuretic, anti-inflammatory and anti-leukemic effects (19$23,32)$. Although HCT was reported to be active against tumors, its anti-colon cancer effect has never been well investigated before. Our studies revealed that $450 \mu \mathrm{g} / \mathrm{ml}$ of HCT might have anti-colon adenocarcinoma activity (Fig. 1) and the activity was concentration- and time-dependent. Previous studies showed that the HCT contains quercetin 3 B-D-glucoside (isoquercitrin) which has anti-HSV activity (33) and quercetin 3-D-galactoside (hyperin) which can inhibit SARS, HBV and herpes viruses (34). HCT also contains chlorogenic acid which has anti-pyretic, anti-HSV and anti-adenovirus effects (35). In this study, we demonstrated that the $50 \%$ ethanol extracts of HCT might have anticolon adenocarcinoma activity. However, further fractionation of the $50 \%$ ethanol extracts in anti-colon adenocarcinoma assays would be required for identification of the bio-active components.

Previously, Chang et al demonstrated that HCT could inhibit five types of leukemia cells (L1210, U937, K562, Raji and P3HR1 cells) with $\mathrm{IC}_{50}$ between $478 \mu \mathrm{g} / \mathrm{ml}$ and $662 \mu \mathrm{g} / \mathrm{ml}$ (21), but the molecular mechanisms of HCT-induced cell death remained unclear. Our results suggested that HCT might exert cytotoxicity by induction of apoptosis and then leads to cell death in HT-29 cells. Based on the results from DAPI staining, Comet assay (Fig. 2A and B) and caspase-3, -9 activity assay (Fig. 4B and C), we demonstrated the HCT might induce apoptosis through caspase-dependent response in HT-29 cells in vitro. Taken together, these findings provide important new possible molecular mechanisms for the anti-colon adenocarcinoma activities of HCT on HT-29 cells.

Apoptosis has two major pathways: the extrinsic (death receptor) pathway and the intrinsic (mitochondria) pathway $(11,12)$. The extrinsic pathway involves Fas, TNF receptor and caspase- 8 which drives its activation and then activates caspase-3 (36). The intrinsic pathway involves the signals to mitochondria, which lead to the release of cytochrome $\mathrm{c}$, Apaf-1, AIF and pro-caspase-9, and then combine with Apaf-1 and pro-caspase-9 to form the apoptosome $(11,13,14)$. Park et al demonstrated that HCT inhibited nitric oxide (NO) production in a dose-dependent manner, but minimally inhibited TNF- $\alpha$ secretion at 0.0625 and $0.125 \mathrm{mg} / \mathrm{ml}$ on macrophage-like cell line (RAW 264.7 cells) (37).

In our results, we found that the HCT does not affect the protein levels of Fas, FasL (data not shown) and caspase- 8 activity (Fig. 4A) in HT-29 cells. We found that the loss of MMP, the increase of ROS production and the alterations of mitochondrial proteins such as cytochrome c, Apaf-1, AIF and pro-caspase-9 in HCT-treated HT-29 cells may suggest that the mitochondria was the major target of HCT (Fig. 5). We also found that by adding caspase- 9 and caspase- 3 inhibitors, we could prevent HCT-treated HT-29 cells from apoptosis (Fig. 4B and C). We concluded that the HCT-induced apoptotic cell death is mediated through the activation of caspase-cascades and that it is mitochondria-dependent. Our novel study demonstrates the involvement of mitochondrialdependent pathways in HCT-induced apoptosis in HT-29 cells.

In conclusion, our results demonstrated that $450 \mu \mathrm{g} / \mathrm{ml}$ of HCT may induce apoptosis in human colon adenocarcinoma HT-29 cells through a mitochondria-dependent pathway.

\section{Acknowledgements}

This study was supported by grants from the China Medical University (CMU95-PH-012, CMU95-PH-010 and CMU95072).

\section{References}

1. People Health Bureau of Taiwan: http://www.doh.gov.tw/ CHT2006/DisplayStatisticFile.aspx?d=71700\&s $=1$

2. Half E and Arber N: Colon cancer: preventive agents and the present status of chemoprevention. Expert Opin Pharmacother 10: 211-219, 2009

3. Sanmartin C, Plano D and Palop JA: Selenium compounds and apoptotic modulation: a new perspective in cancer therapy. Mini Rev Med Chem 8: 1020-1031, 2008.

4. Rudolf E, Kralova V and Cervinka M: Selenium and colon cancer - from chemoprevention to new treatment modality. Anticancer Agents Med Chem 8: 598-602, 2008.

5. Clarke JD, Dashwood RH and Ho E: Multi-targeted prevention of cancer by sulforaphane. Cancer Lett 269: 291-304, 2008.

6. Qiao L and Wong BC: Targeting apoptosis as an approach for gastrointestinal cancer therapy. Drug Resist Updat 12: 55-64, 2009.

7. Millan A and Huerta S: Apoptosis-inducing factor and colon cancer. J Surg Res 151: 163-170, 2009.

8. Visconti R and Grieco D: New insights on oxidative stress in cancer. Curr Opin Drug Discov Devel 12: 240-245, 2009.

9. Meyn RE, Milas L and Ang KK: The role of apoptosis in radiation oncology. Int J Radiat Biol 85: 107-115, 2009.

10. Martin FA, Perez-Garijo A and Morata G: Apoptosis in Drosophila: compensatory proliferation and undead cells. Int J Dev Biol (In press).

11. Petit E, Oliver L and Vallette FM: The mitochondrial outer membrane protein import machinery: a new player in apoptosis? Front Biosci 14: 3563-3570, 2009.

12. Murgia M, Giorgi C, Pinton P and Rizzuto R: Controlling metabolism and cell death: At the heart of mitochondrial calcium signalling. J Mol Cell Cardiol 46: 781-788, 2009.

13. Kong GY, Van Bergen NJ, Trounce IA and Crowston JG: Mitochondrial dysfunction and glaucoma. J Glaucoma 18: 93-100, 2009.

14. Gogvadze V, Orrenius S and Zhivotovsky B: Mitochondria as targets for chemotherapy. Apoptosis 14: 624-640, 2009.

15. Peralta-Leal A, Rodriguez MI and Oliver FJ: Poly(ADP-ribose) polymerase-1 (PARP-1) in carcinogenesis: potential role of PARP inhibitors in cancer treatment. Clin Transl Oncol 10: 318-323, 2008.

16. Cepeda V, Fuertes MA, Castilla J, et al: Poly(ADP-ribose) polymerase-1 (PARP-1) inhibitors in cancer chemotherapy. Recent Pat Anticancer Drug Discov 1: 39-53, 2006.

17. Schauer T, Tombacz I, Ciurciu A, Komonyi O and Boros IM: Misregulated RNA Pol II C-terminal domain phosphorylation results in apoptosis. Cell Mol Life Sci 66: 909-918, 2009.

18. Chiang LC, Chang JS, Chen CC, Ng LT and Lin CC: Anti-Herpes simplex virus activity of Bidens pilosa and Houttuynia cordata. Am J Chin Med 31: 355-362, 2003.

19. Lee JS, Kim IS, Kim JH, Kim JS, Kim DH and Yun CY: Suppressive effects of Houttuynia cordata Thunb (Saururaceae) extract on Th2 immune response. J Ethnopharmacol 117: 34-40, 2008.

20. Li GZ, Chai OH, Lee MS, Han EH, Kim HT and Song CH: Inhibitory effects of Houttuynia cordata water extracts on anaphylactic reaction and mast cell activation. Biol Pharm Bull 28: 1864-1868, 2005 .

21. Chang JS, Chiang LC, Chen CC, Liu LT, Wang KC and Lin CC: Antileukemic activity of Bidens pilosa L. var. minor (Blume) Sherff and Houttuynia cordata Thunb. Am J Chin Med 29: 303-312, 2001. 
22. Hayashi K, Kamiya M and Hayashi T: Virucidal effects of the steam distillate from Houttuynia cordata and its components on HSV-1, influenza virus, and HIV. Planta Med 61: 237-241, 1995.

23. Chen YY, Liu JF, Chen CM, Chao PY and Chang TJ: A study of the antioxidative and antimutagenic effects of Houttuynia cordata Thunb. using an oxidized frying oil-fed model. J Nutr Sci Vitaminol (Tokyo) 49: 327-333, 2003.

24. Flis S and Splwinski J: Inhibitory effects of 5-fluorouracil and oxaliplatin on human colorectal cancer cell survival are synergistically enhanced by sulindac sulfide. Anticancer Res 29: 435-441, 2009.

25. Yang JS, Chen GW, Hsia TC, et al: Diallyl disulfide induces apoptosis in human colon cancer cell line (COLO 205) through the induction of reactive oxygen species, endoplasmic reticulum stress, caspases casade and mitochondrial-dependent pathways. Food Chem Toxicol 47: 171-179, 2009.

26. Ip SW, Liao SS, Lin SY, et al: The role of mitochondria in bee venom-induced apoptosis in human breast cancer MCF7 cells. In Vivo 22: 237-245, 2008

27. Lin SY, Lai WW, Ho CC, et al: Emodin induces apoptosis of human tongue squamous cancer SCC-4 cells through reactive oxygen species and mitochondria-dependent pathways. Anticancer Res 29: 327-335, 2009.

28. Lin YT, Yang JS, Lin SY, et al: Diallyl disulfide (DADS) induces apoptosis in human cervical cancer Ca Ski cells via reactive oxygen species and $\mathrm{Ca}^{2}{ }^{+}$-dependent mitochondria-dependent pathway. Anticancer Res 28: 2791-2799, 2008.

29. Chung JG, Yang JS, Huang LJ, et al: Proteomic approach to studying the cytotoxicity of YC-1 on U937 leukemia cells and antileukemia activity in orthotopic model of leukemia mice. Proteomics 7: 3305-3317, 2007.
30. Lu KW, Tsai ML, Chen JC, et al: Gypenosides inhibited invasion and migration of human tongue cancer SCC4 cells through down-regulation of NFkappaB and matrix metalloproteinase-9. Anticancer Res 28: 1093-1099, 2008.

31. Yang JS, Hour MJ, Kuo SC, Huang LJ and Lee MR: Selective induction of G2/M arrest and apoptosis in HL-60 by a potent anticancer agent, HMJ-38. Anticancer Res 24: 1769-1778, 2004.

32. Kusirisin W, Srichairatanakool S, Lerttrakarnnon P, et al: Antioxidative activity, polyphenolic content and anti-glycation effect of some thai medicinal plants traditionally used in diabetic patients. Med Chem 5: 139-147, 2009.

33. Abou-Karam M and Shier WT: Isolation and characterization of an antiviral flavonoid from Waldsteinia fragarioides. J Nat Prod 55: 1525-1527, 1992.

34. Wu LL, Yang XB, Huang ZM, Liu HZ and Wu GX: In vivo and in vitro antiviral activity of hyperoside extracted from Abelmoschus manihot (L) medik. Acta Pharmacol Sin 28: 404-409, 2007.

35. Lin TY, Liu YC, Jheng JR, et al: Anti-enterovirus 71 activity screening of chinese herbs with anti-infection and inflammation activities. Am J Chin Med 37: 143-158, 2009.

36. Autefage H, Albinet V, Garcia V, et al: The lysosomal serine protease CLN2 regulates TNF alpha-mediated apoptosis in a bid-dependent manner. J Biol Chem 284: 11507-11516, 2009.

37. Park E, Kum S, Wang C, Park SY, Kim BS and Schuller-Levis G: Anti-inflammatory activity of herbal medicines: inhibition of nitric oxide production and tumor necrosis factor-alpha secretion in an activated macrophage-like cell line. Am J Chin Med 33: 415-424, 2005 